\title{
Peningkatan Aktivitas Pemasaran UMKM Melalui Pengembangan Website D'real Potatoes di Jakarta
}

\author{
Franky Selamat ${ }^{1 *}$, Bagus Mulyawan ${ }^{2 *}$, Hetty Karunia Tunjungsari ${ }^{3 *}$ \\ ${ }^{1,3}$ Fakultas Ekonomi dan Bisnis Universitas Tarumanagara, Jakarta Barat, 11470 \\ ${ }^{2}$ Fakultas Teknologi Informasi, Universitas Tarumanagara, Jakarta Barat, 11410 \\ Author E-mail \\ frangkys@fe.untar.ac.id,bagus@untar.ac.id, hetty@fe.untar.ac.id \\ *Penulis adalah tim peneliti dari Pusat Studi Kewirausahaan, Lembaga Penelitian dan \\ Pengabdian Masyarakat Universitas Tarumanagara
}

\begin{abstract}
A B S T R A K
Memulai sebuah usaha startup adalah sebuah perjuangan yang penting dalam proses kewirausahaan. Startup mempunyai bisnis model yang berbeda dengan bisnis yang konvensional. Startup memiliki terobosan yang tidak dimiliki oleh bisnis konvensional sebelumnya. Model bisnis adalah gambaran umum dari proses pengembangan ide bisnis, mulai dari perencanaan sampai produk diproduksi dan dipasarkan. Menjalankan sebuah usaha mikro, kecil dan menengah (UMKM) tidak sama dengan menjalankan sebuah startup. Namun UMKM dapat dikembangkan menjadi sebuah startup bila didukung dengan pengembangan bisnis model secara optimal. Pengabdian masyarakat (Abdimas) ini dilakukan untuk membantu UMKM berkembang dengan meningkatkan aktivitas pemasarannya melalui pengembangan website. Ini adalah langkah awal untuk mengembangkan sebuah UMKM menjadi sebuah startup berbasis digital
\end{abstract}

Kata Kunci: Start-up Business, MSME, Marketing Activities.

\section{A B S T R A C T}

Launching a start-up (starting abusiness) is an ideal form of the entrepreneurial process. Astartup is a business that has a different business model compared to the existing conventional businesses. There should be a breakthrough to the pre-existing business model. Business model is a general description of a business creating process, which is conveyed and valued, from the initial phase until the products is produced and marketed. Establishing and running a Micro, Small and Medium Enterprises (MSMEs) is not the same as a start-up business. However, MSMEs can develop into start-ups if they are properly developed, by providing support in designing their business models. This community engagement activity is carried out to help one of the fostered MSMEs to grow its business by increasing marketing activities through website development. The development of a website can boost marketing activities and become the first step for MSMEs to grow as digital-based startup business.

Keywords: Start-up Business, MSME, Marketing Activities.

Copyright (C) 2020 Authors. This is an open access article distributed under the Creative Commons Attribution License, which permits unrestricted use, distribution, and reproduction in any medium, provided the original work is properly cited. 


\section{PENDAHULUAN}

\section{Analisis Situasi}

Start-up business (usaha rintisan) merupakan usaha yang memiliki model bisnis berbeda dibandingkan bisnis konvensional yang telah ada. Di dalamnya terdapat terobosan atau inovasi terhadap model bisnis yang telah ada sebelumnya. Usaha rintisan juga fokus pada pertumbuhan. Sebagaimana diketahui, model bisnis merupakan gambaran umum mengenai bagaimana sebuah usaha mencipta, menyampaikan dan menangkap nilai, dari produk yang dihasilkan. Tidak semua usaha dapat dikategorikan sebagai usaha rintisan, jika tetap menggunakan model bisnis yang biasa digunakan. Pada umumnya UMKM merupakan bisnis konvensional, sehingga tidak dapat disebut sebagai usaha rintisan.

Meskipun mayoritas UMKM bukanlah usaha rintisan, namun kontribusi yang diberikan terhadap perekonomian nasional tidak dapat dipandang remeh. Kontribusi UMKM terhadap produk domestik bruto (PDB) meningkat dari 57,84 persen menjadi 60,34 persen dalam lima tahun terakhir. Serapan tenaga kerja pada sektor ini juga meningkat dari 96,99 persen menjadi 97,22 persen pada periode yang sama.

Jika mengacu pada UU Republik Indonesia Nomor 20 Tahun 2008 tentang UMKM, maka kriteria UMKM adalah sebagai berikut:

Di dalam UU tersebut juga disebutkan peran Pemerintah dan Pemerintah Daerah dalam membangun dan menumbuhkan UMKM. Dukungan pemerintah diberikan dari segi pendanaan hingga promosi. Peran serta pemerintah memang menjadi salah satu penentu keberhasilan, walaupun anggota masyarakat lain pun dapat berkontribusi terhadap perkembangan UMKM.
Universitas Tarumanagara sebagai universitas yang mengedepankan nilai-nilai kewirausahaan tentu dapat menjadi garda terdepan untuk memajukan UMKM. Kurikulum pendidikan kewirausahaan memang tidak ditargetkan untuk melahirkan UMKM, namun demikian UMKM yang berkembang dengan baik dapat menjadi cikal bakal lahirnya usaha rintisan, dengan inovasi model bisnis seperti yang telah diuraikan sebelumnya. UMKM yang berkembang menjadi usaha rintisan akan memberikan nilai tambah bagi perekonomian nasional.

D'Real Potatoes adalah salah satu contoh UMKM yang merupakan inisiasi dari anak muda yang mencoba berkreasi dan berinovasi. Dari segi model bisnis, memang belum terdapat terobosan berarti. Produk yang dihasilkan murni homemade dengan mengedepankan bahan baku alami dan proses produksi yang sederhana.

Sesuai namanya, D'Real Potatoes merupakan keripik kentang dengan irisan kentang asli yang kadarnya mencapai hingga 90 persen, berbeda dengan produk sejenis produksi pabrikan besar yang kadar kentangnya justru kurang dari 60 persen, dan selebihnya merupakan campuran berbagai zat. Keunggulan D'Real Potatoes yang lain adalah pada bahan baku asli alami dan proses produksi yang sederhana namun menjamin rasa yang khas. UMKM ini belum terlalu berkembang dari segi penjualan. Aktivitas penjualan baru pada kalangan terbatas dan belum ada inisiasi untuk mengembangkan menjadi usaha yang lebih maju, walaupun memiliki potensi yang cukup untuk itu.

Program Pengabdian Kepada Masyarakat (PKM) ini merupakan bagian dari upaya pembinaan yang dilakukan oleh Pusat Studi Kewirausahaan UNTAR untuk turut membina dan mengembangkan

Tabel 1.1. Kriteria UMKM menurut UU Nomor 20 Tahun 2008

\begin{tabular}{llcc}
\hline Kriteria & \multicolumn{1}{c}{ Mikro } & Kecil & Menengah \\
\hline $\begin{array}{l}\text { Kekayaan Bersih (tidak termasuk } \\
\text { tanah dan bangunan tempat usaha) } \\
\text { Penjualan Tahunan }\end{array}$ & Paling banyak Rp 50 juta & Rp 50 juta - Rp 500 juta & Rp 500 juta - Rp 10 milyar \\
\cline { 2 - 4 } & Paling banyak Rp 300 juta & Rp 300 juta - Rp 2,5 milyar & Rp 2,5 milyar - Rp 50 milyar \\
\hline
\end{tabular}

Sumber: Franky Slamet dkk, 2018 
UMKM, sebagai langkah nyata yang berkontribusi terhadap perekonomian Indonesia. Di era digital, perkembangan UMKM tentu juga dipengaruhi oleh pemanfaatan teknologi informasi dalam pengelolaan usahanya. El-Gohary (2012) dan Nuseir (2018) mengemukakan bahwa media digital dan teknik e-marketing dapat banyak membantu dalam pertumbuhan UMKM dan dapat meningkatkan kinerja secara signifikan. Sentuhan digital menjadi fokus dari kegiatan PKM ini dengan harapan bahwa D'Real Potatoes dapat meningkatkan kinerja penjualan dengan memperluas jangkauan pasar.

\section{Permasalahan Mitra}

UMKM yang dijalankan dengan segala potensi yang ada, belum memberikan hasil yang optimal. Salah satu indikatornya adalah tingkat penjualan yang masih rendah. Potensi pasar yang ada belum tergarap dengan baik. Berdasarkan diskusi dengan pendiri dan pemilik usaha ini, diperlukan terobosan, agar usaha yang dijalankan dapat lebih berdaya saing. Salah satunya adalah meningkatkan aktivitas pemasaran dengan menggunakan media digital selain media sosial yang telah dijalankan sebelumnya. Saat ini, D'Real Potatoes telah memanfaatkan sosial media sebagai salah satu sarana mempromosikan produknya. Namun demikian, penggunaan sosial media ini belum dapat dirasakan manfaatnya karena pengelolaannya masih kurang optimal.

\section{Solusi yang Ditawarkan}

Kegiatan PKM ini diharapkan mampu meningkatkan kapasitas pemasaran UMKM binaan, yang selanjutnya menjadi langkah awal bertransformasi menjadi usaha rintisan berbasis digital. Luaran yang dihasilkan dari kegiatan PKM ini adalah berupa website yang menampilkan profil UMKM D’Real Potatoes.

\section{Tinjauan Teori}

\section{Usaha Rintisan (Start-up)}

Menurut Merriam-Webster, usaha rintisan diartikan sebagai "tindakan atau contoh pengaturan dalam operasi atau gerakan" atau "perusahaan bisnis yang masih muda." Sementara American Heritage mendefinisikan Dictionary mendefinisikan usaha rintisan sebagai "sebuah bisnis atau usaha yang baru-baru ini mulai beroperasi."

Memulai sebuah usaha dapat menjadi pengalaman yang menggembirakan, namun bagi pemilik usaha rintisan atau bisnis yang baru lahir, berbagai tantangan yang mereka hadapi seringkali mengikis kegembiraan ini. Sejumlah penelitian membahas tantangan yang dihadapi usaha rintisan di berbagai bidang, seperti di industri kreatif, teknologi, kesehatan, hingga jasa (Gornostaeva, Rieple, \& Barnes, 2014; Henry \& de Bruin, 2011; Mills, 2011; Yanyuan \& Shikui, 2016).

Untuk dapat bertahan pada masa-masa awal pendirian usaha dan meraih keberhasilan usaha dalam jangka panjang, usaha rintisan perlu memperhatikan sejumlah hal berikut: memahami pentingnya modal sosial dan jaringan untuk mengamankan keuangan, mengelola waktu, produksi, bahan sumber daya dan informasi terkait pertumbuhan dan menunjukkan bagaimana jaringan berubah.

\section{Aktivitas Pemasara}

Kegiatan pemasaran menggambarkan keputusan dan masalah yang berkaitan dengan produk, harga, promosi dan distribusi (McCarthy \& Perrault, 1993). Pemasaran yang efektif menjanjikan beberapa manfaat bagi perusahaan seperti peningkatan laba, peningkatan penjualan, peningkatan kepuasan pelanggan, pengembangan citra perusahaan, pengembangan produk / layanan, pintu masuk ke pasar baru, penciptaan pasar baru, peningkatan loyalitas pelanggan, peningkatan reputasi, peningkatan kualitas total, dan lain-lain (Dikmen etal., 2005).

Tujuan utama kegiatan pemasaran adalah untuk memahami dan memenuhi kebutuhan pelanggan. Tujuan ini akan tercapai ketika semua komponen sistem pemasaran, yaitu, pemasok dan distributor dapat berkoordinasi dan bekerja secara harmonis. Kegiatan pemasaran yang disusun dengan baik dan efektif akan memfasilitasi pencapaian tujuan organisasi yang khas seperti penjualan tinggi, 
pangsa pasar, keuntungan dan keunggulan kompetitif (Buzzell dan Gale, 1987; Kotler, 2018; Polat dan Donmez, 2010).

Dalam konteks UMKM, aktivitas pemasaran sangat menentukan keberhasilan UMKM dalam menjalankan bisnisnya. UMKM yang memiliki pemahaman tentang praktik pemasaran yang efektif seperti misalnya memahami proses perencanaan pemasaran, perlu didorong untuk mengimplementasikan konsep pemasaran formal secara lebih lanjut (Hill, 2001). Lebih lanjut Hill (2001) mengemukakan bahwa UMKM perlu mendapatkan pendampingan secara intensif agar dapat menengembangan dan mengimplementasikan aktivitas pemasaran formal layaknya perusahaan-perusahaan besar.

\section{METODE PELAKSANAAN}

Metode pelaksanaan yang akan digunakan dalam kegiatan ini adalah sebagai berikut:

a. Pengumpulan data dan penyusunan proposal Dalam menyusun proposal kegiatan PKM, tim melakukan wawancara dengan pemilik dan pendiri UMKM D'Real Potatoes untuk mengidentifikasi masalah mitra. Setelah diketahui permasalahan yang dihadapi mitra, tim PKM melakukan studi literatur untuk mencari solusi yang tepat bagi permasalahan mitra.

D'Real Potatoes merupakan usaha yang didirikan oleh Daniel Gunawan, alumni Program Studi Sarjana Manajemen, Fakultas Ekonomi dan Bisnis Universitas Tarumanagara tahun 2018. Pada saat kuliah dia mengambil konsentrasi Kewirausahaan \& Manajemen Bisnis dan juga sempat mengikuti acara "Entrepreneur Week", ajang bagi mahasiswa konsentrasi kewirausahaan untuk menampilkan prototype produk dari model bisnis. Berbeda ketika Daniel tampil di ajang tersebut, usaha ini merupakan bisnis yang dikembangkan dan dijalankan sendiri, tidak bersama tim "Entrepreneur Week" yang lalu. Acara tersebut telah memotivasi Daniel untuk memulai dan mengembangkan usahanya sendiri.
Sesuai namanya “D'Real Potatoes", usaha ini menghasilkan keripik kentang, yang menurutnya benar-benar riil, meminimalkan campuran bahan pendukung lain, sebagaimana keripik kentang buatan pabrikan besar. Kadar kentang mencapai 90\%, sisanya bahan lain untuk memperkuat rasa, hal yang sebaliknya pada produk dari produsen besar ternama.

Keripik ini terdiri atas enam macam rasa yaitu: ayam bakar, sambal balado, original salt, keju manis, pizza dan jagung bakar, seperti yang ditampilkan pada gambar 2.1. berikut ini:

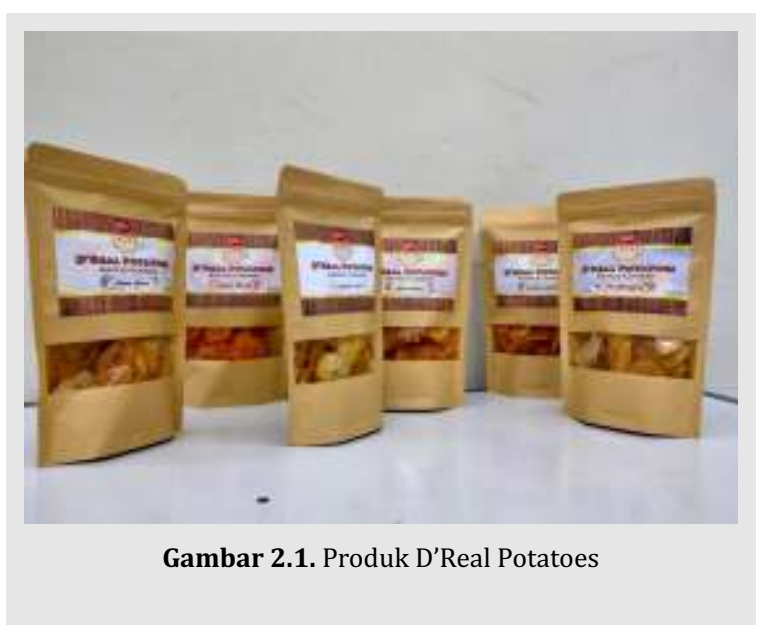

Saat ini produk D'Real Potatoes dipasarkan berdasarkan "pertemanan" memanfaatkan jejaring yang dimiliki pemiliknya. Karena masih mengandalkan jaringan yang terbatas maka hasilnya pun tidak dapat dikatakan memuaskan jika dibandingkan dengan potensi yang dimiliki. Menurut pengakuan Daniel, penjualan rata-rata per bulan 100-150 bungkus, dengan harga per bungkus Rp 20.000,- sehingga omsetnya berkisar pada $\mathrm{Rp} 2.500 .000$,- per bulan.

Keunggulan yang dimiliki produk ini adalah penggunaan bahan alami yang mencapai $90 \%$, tidak menggunakan pengawet. Namun produk tidak didukung oleh proses produksi yang standar, suplai bahan baku terjamin dan strategi penjualan dan pemasaran yang terpadu. Kemasan juga masih sederhana. Proses produksi juga masih menggunakan alatalat yang sederhana. 
b. Pelaksanaan

Pelaksanaan kegiatan PKM adalah dengan melakukan kunjungan ke tempat UMKM. Selain melakukan observasi di tempat usaha, tim juga berdiskusi dengan pemilik UMKM tersebut untuk menentukan solusi efektif untuk kegiatan pemasaran yang lebih berdaya saing. Selain itu terkait dengan pengembangan website, tim juga melakukan konsultasi mengenai desain dan konten website yang diperlukan.

Selain menyusun website, pelaksanaan kegiatan PKM ini juga melibatkan survei pada pelanggan yang akan mengakses website yang telah dikembangkan oleh tim PKM. Tujuan melakukan survei ini adalah untuk mengetahui respons pelanggan saat mengakses website D'Real Potatoes, apakah terdapat kendala dalam mengakses website dan apakah website yang dikembangkan mampu memenuhi kebutuhan pelanggan.

Untuk meningkatkan kinerja, dengan potensi yang dimiliki tersebut tim PKM UNTAR mengadakan diskusi dengan Daniel seperti yang ditampilkan pada gambar 2.2 berikut ini:

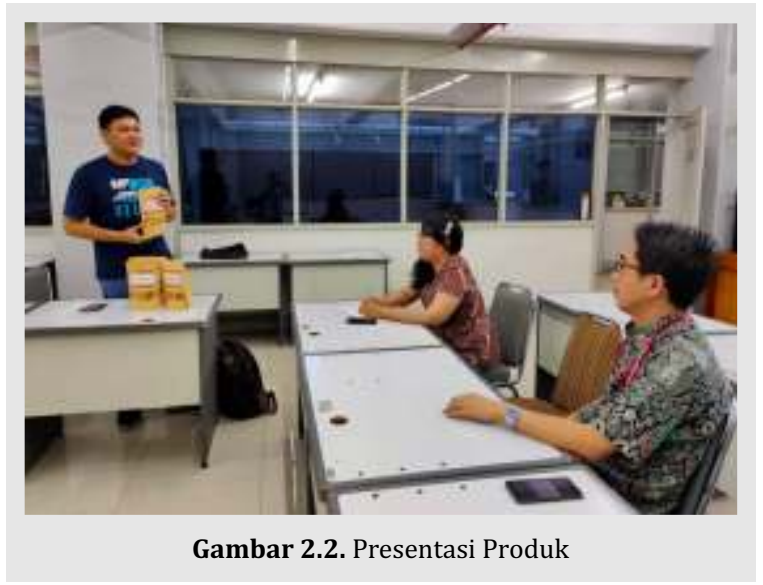

Untuk meningkatkan kinerja penjualan sekaligus juga untuk membenahi aspek branding, tim PKM menawarkan kepada D'Real Potatoes untuk memiliki website usaha yang sekaligus juga dapat digunakan sebagai sarana untuk menerima pesanan. Langkah awal adalah penyusunan profil perusahaan yang akan ditampilkan di dalam website tersebut:

Tabel 2.1. Profil D'Real Potatoes

Kentang goreng adalah camilan yang kian populer di dunia saat ini. Pertama kali dijual di Perancis pada tahun 1789 oleh penjaja makanan kaki lima. Kemudian pada tahun 1950 perusahaan cepat saji asal Amerika menciptakan kentang goreng yang lezat dan bisa disimpan dalam waktu lama. Dari situlah kentang goreng menjadi sangat populer di seluruh dunia. Seperti diketahui saat ini banyak restoran cepat saji di Indonesia menyajikan makanan yang terbuat dari kentang dalam berbagai macam. Saat ini juga diketahui banyak perusahaan berskala besar yang memproduksi keripik kentang secara massal, yakni seperti: Pringles, Lays, Potabee, Chitato, Japota, dan masih banyak merek lainnya. Kebanyakan dari produk tersebut tidak berkomposisi 100\% kentang murni (adanya campuran bahan lain).

“D’Real Potatoes" adalah keripik kentang yang diproduksi langsung dari 100\% kentang murni yang dikupas, diserut dan di goreng secara manual per batch (Kettle Cooked) yang menggunakan minyak goreng sawit berkualitas dan digoreng kuali stainless steel SUS 304 (food grade). Keripik kentang “D’Real Potatoes” sangat mengutamakan kualitas, kebersihan dan kesehatan konsumen. Produk yang telah digoreng langsung ditiriskan selama 10 menit dan kemudian didiamkan di tisu peniris minyak selama 25 menit (agar minyak kering sempurna). Saat ini produk "D’Real Potatoes" memiliki 6 varian rasa unik, yakni: Original, jagung bakar, ayam bakar, sambal balado, keju manis, dan sapi panggang. Penggunaan bumbu yang diberikan adalah bumbu yang sudah mendapatkan BPOM dan berlogo HALAL.

D'Real Potatoes mulai memproduksi sampel pada tanggal 18 Juli 2019, yang dibagikan ke keluarga, tetangga, dan 
kenalan-kenalan pemilik yang pada saat itu langsung memikat hati kepada setiap orang yang mencobanya di mana mayoritas memberikan masukkan bahwa produk "enak", "tidak berminyak" dan sudah layak dipasarkan. Segmentasi pasar pada produk ini adalah orang berumur 18-40 tahun yang suka camilan.

Visi D'Real Potatoes adalah menjadi perusahaan camilan terkemuka di Indonesia dengan menyajikan menu keripik kentang yang berkomposisi $100 \%$ murni dari kentang dieng asli yang berkualitas tinggi. Misi D'Real Potatoes adalah mengutamakan kualitas produk, mempertahankan produk tetap gluten free, menggunakan peralatan produksi yang $100 \%$ food grade, keramahan pelayanan, dan menciptakan pengalaman tersendiri bagi pelanggan.

Pemilik bisnis ini adalah Daniel Gunawan, dengan alamat email: danielgunawan27 @yahoo.co.id, kontak bisnis melalui WA dengan nomor 08176930399.

\section{c. Pelaporan}

Kegiatan ini dilaksanakan untuk UMKM D'Real Potatoes. Tujuan kegiatan PKM adalah untuk meningkatkan aktivitas pemasaran melalui pengembangan website. Setelah kegiatan ini dilaksanakan maka tim PKM akan menyusun laporan dan menyusun draft publikasi terkait dengan kegiatan ini. Hasil dari kegiatan ini nantinya akan dijadikan dasar untuk menyusun rencana kegiatan lanjutan.

\section{HASIL DAN PEMBAHASAN}

Saat ini telah dikembangkan, website D'Real Potatoes yang di dalamnya menampilkan aneka ragam rasa produk dengan gambar-gambar yang menarik seperti ditampilkan pada Gambar 3.1. berikutini:

Selain menampilkan profil produk dan bisnis, website juga menampilkan informasi mengenai pemesanan melalui layanan Whats App dan info ketersediaan produk. Walaupun belum dapat digunakan untuk memproses pesanan secara online namun D'Real Potatoes dapat mulai menyebarkan informasi tentang bagaimana melakukan pemesanan, seperti info Whats App. Harapannya adalah dengan pengembangan website ini dapat membantu D'Real Potatoes untuk meningkatkan jangkauan pemasaran yang pada akhirnya dapat meningkatkan volume penjualan yang saat ini baru mencapai 100-150 bungkus per bulan.

Alamat website D'Real Potatoes adalah: www.drealpotatoes.com, seperti yang disajikan pada gambar 3.2 berikut ini yang merupakan tampilan di ponsel:
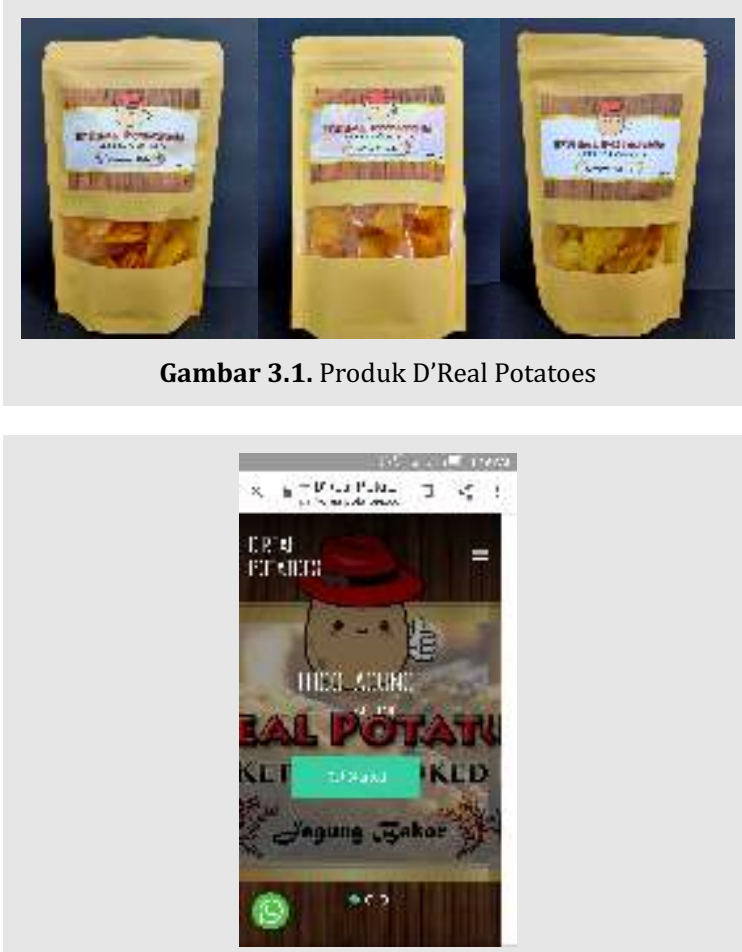

Gambar 3.2. Tampilan website Rasa Jagung Bakar

Tampilan seperti yang disajikan pada gambar 3.2. memang belum sempurna, seperti masih tampak tulisan "logo jagung". Tampilan tersebut merupakan screenshot dari ponsel. Diharapkan calon konsumen D'Real Potatoes dapat mengakses dari ponselnya sekaligus melakukan pemesanan secara langsung, walaupun transaksi penjualan masih dijalankan secara konvensional, yaitu transfer via atm atau mobile banking.

Daniel selaku pemilik sekaligus pengelola website 
ini juga telah dilatih selaku administrator seperti ditampilkan pada Gambar 3.3. agar dapat memperbarui isi website, terutama mengenai informasi ketersediaan produk serta info-info lain seperti event yang diikuti D'Real Potatoes. Acara yang menjadi sasaran untuk diikuti adalah bazaar yang kerap diadakan di kampus atau pentas seni mahasiswa.

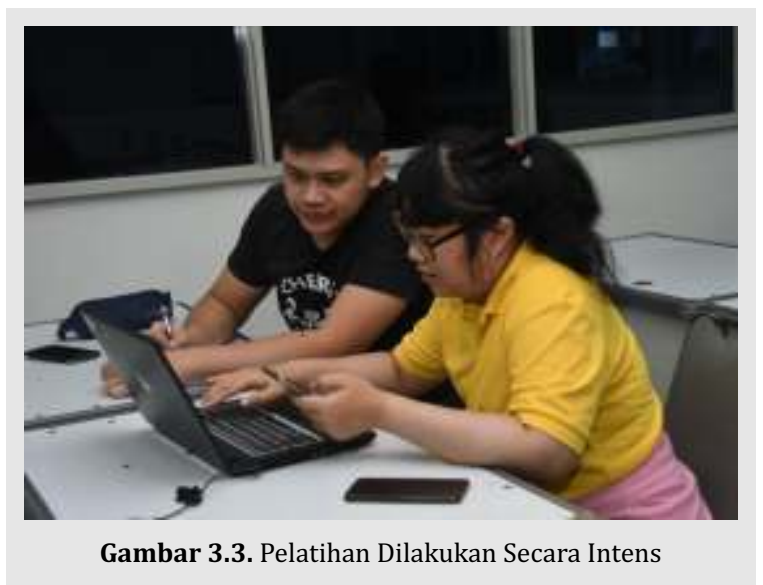

Sebagai administrator, Daniel dapat memperbarui foto-foto yang ditampilkan di dalam website. Foto-foto tersebut tidak cuma foto produk saja, namun juga kegiatan yang diikuti dalam rangka mempromosikan produk. Dengan memperbarui foto-foto tersebut, diharapkan website akan terlihat selalu aktual dan mengikuti kondisi terkini.

Seperti yang ditampilkan pada Gambar 3.4. berikut, sebagai administrator, Daniel harus melakukan login terlebih dahulu untuk melakukan serangkaian update informasi.
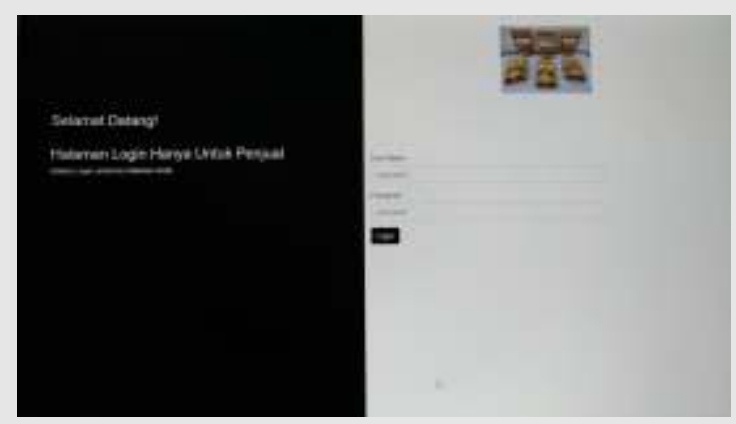

Gambar 3.4. Halaman Login Penjual

Selain foto-foto kegiatan, Daniel juga dapat melakukan update terhadap harga produk seperti disajikan pada Gambar 3.5.
Harga memang hal yang amat sensitif. Melalui diskusi yang intens dengan Daniel, harga yang ditampilkan juga akan menampilkan tawaran potongan harga jika dilakukan pemesanan dalam jumlah tertentu.

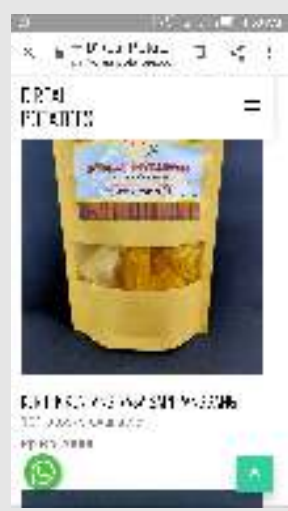

Gambar 3.5. Tampilan Harga Produk dan Ketersediaan

Pada gambar 3.6. disajikan tampilan website D'Real Potatoes secara utuh dari layar monitor komputer yang menampilkan menu: home, products, recommended products, about, contact dan seller login.

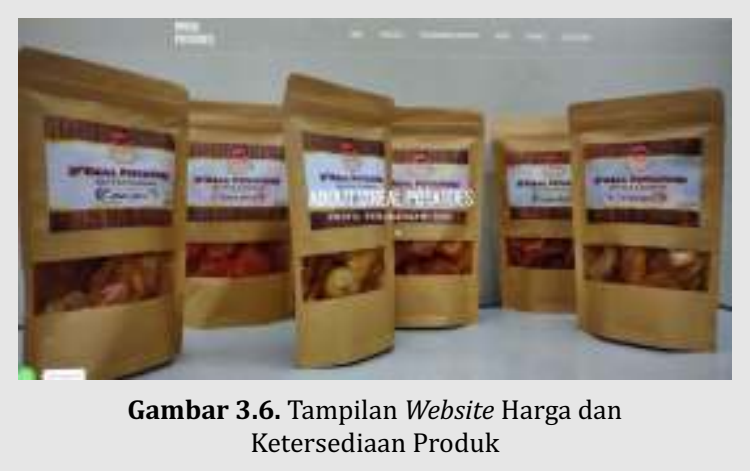

Setelah website ini dijalankan, langkah selanjutnya adalah menyebarkan link website tersebut ke berbagai grup Whats App yang selama ini menjadi bagian dari komunitas yang disasar D’Real Potatoes. Awalnya terdapat kesulitan beberapa pelanggan yang biasa membeli produk D’Real Potatoes untuk mengakses website tersebut dengan tampilan di layar monitor komputer bahwa alamat website tersebut tidak aman.

Hasil survei pada calon konsumen D'Real Potatoes untuk mengetahui persepsi mereka terhadap tampilan website yang telah dikembangkan menunjukkan respon positif dari para pengunjung 
website. Survey ini dilakukan untuk mengetahui persepsi calon pembeli dalam hal kemudahan mereka memperoleh informasi mengenai produk D'Real Potatoes, kemudahan dalam mengakses website D'Real Potatoes, kelengkapan informasi yang ditampilkan dalam website, serta kemenarikan website.

Survey dilakukan dengan cara menyebarkan link website ke sejumlah pelanggan tetap D'Real Potatoes. Terdapat 30 responden yang merespon survey, dimana 24 responden adalah wanita dan 8 responden adalah pria. Responden berusia antara 16 tahun hingga 45 tahun, dengan latar belakang Pendidikan SMA hingga S3. Seluruh responden berdomisili di Jabodetabek.

Sebanyak 83,3\% atau 25 responden menyatakan bahwa mereka Setuju dengan pertanyaan tentang kemudahan memperoleh informasi mengenai produk D'Real Potatoes dan $16,6 \%$ atau 5 responden menyatakan Netral dengan pertanyaan ini. 20 responden Setuju bahwa website D'Real Potatoes mudah diakses, 6 responden menyatakan Netral, dan 4 sisanya menyatakan Tidak Setuju.

Terdapat sebanyak 16 responden menyatakan Setuju bahwa informasi yang ditampilkan dalam website D'Real Potatoes lengkap, 5 responden menyatakan Sangat Setuju, 3 responden menyatakan Netral, dan 7 responden menyatakan Tidak Setuju. Adapun terkait dengan kemenarikan website, 21 responden menyatakan Setuju bahwa website D'Real Potatoes menarik dan 9 sisanya menyatakan Netral.

Kegiatan PKM ini memberikan kontribusi bagi masyarakat sesuai dengan latar belakang keilmuan tim PKM, yakni bidang Pemasaran, Kewirausahaan dan Sistem Informasi. Tim PKM telah melakukan transfer pengetahuan di bidang ilmu tersebut dalam bentuk konsultasi pengembangan website hingga proses peluncuran website sebagai upaya meningkatkan aktivitas pemasaran D'Real Potatoes. Penambahan fasilitas website sebagai salah satu layanan UMKM untuk mempermudah konsumen dalam mendapatkan informasi dan melakukan proses pembelian produk diharapkan mampu meningkatkan aktivitas pemasaran UMKM. Hal ini sejalan dengan praktik pendampingan UMKM dalam penelitian Hill (2001).

Di masa mendatang, kegiatan PKM serupa dapat dilakukan pada usaha rintisan maupun UMKM yang telah menjalankan bisnisnya namun belum memanfaatkan media digital sebagai sarana promosi maupun pendukung kegiatan pemasaran lainnya. Pengembangan website bagi UMKM relative mudah dilakukan dan memiliki manfaat yang besar jika dapat dikelola dengan optimal. Website yang dikembangkan nantinya sebaiknya juga dapat diakses dengan mudah baik melalui browser di komputer maupun di ponsel. Hal ini sangat penting karena saat ini mayoritas konsumen lebih mudah mengakses website melalui ponsel dibandingkan harus membuka di komputer.

\section{KESIMPULAN DAN SARAN}

Program pengabdian masyarakat ini menarik beberapa kesimpulan.

\section{Kesimpulan}

Setelah tim PKM melaksanakan serangkaian aktivitas terhadap D'Real Potatoes maka dapat ditarik kesimpulan sebagai berikut:

1. Usaha D'Real Potatoes masih dalam tahap prestartup yang masih memerlukan bimbingan agar dapat berjalan secara berkesinambungan, sehingga benar-benar menjadi startup yang sesungguhnya.

2. Selain pembenahan dari aspek pemasaran, sisi legalitas yang terkait dengan proses produksi juga harus mendapat perhatian, misalnya memperoleh PIRT dari Dinas Kesehatan (Dinkes). Aspek ini mempengaruhi juga sisi pemasaran, karena tanpa legalitas ini, tidak diperkenankan untuk dijual hingga di luar provinsi. PIRT menjadi syarat minimal sebuah produk makanan memenuhi standar kesehatan, sehingga hak konsumen terlindungi.

1. Keberadaan website D'Real Potatoes dapat 
memperluas pasar, walaupun link tersebut harus disebarluaskan ke berbagai grup di media sosial.

\section{Saran}

Saran yang dapat disampaikan adalah sebagai berikut:
1. Diperlukan kelanjutan dari kegiatan PKM yang terkait aktivitas lain seperti branding, produksi dan legalitas.

2. Pembinaan dapat dilakukan pada jenis usaha lain dalam rangka memberdayakan usahausaha mikro.

\section{DAFTAR PUSTAKA}

Buzzell, R. and Gale, B. (1987), The PIMS Princi-ples, Free Press, New York, NY.

Dikmen, I., Birgonul, M.T. and Ozcenk, I. (2005). Marketing orientation in construction firms: evidence from Turkish contractors. Building and Environment, Vol. 40, pp. 257-65.

El-Gohary, Hatem (2012). Expanding TAM and IDT to Understand the Adoption of E-Marketing by Small Business Enterprises: An Empirical Investigation in E-Marketing: Concepts, Methodologies, Tools and Applications, IGI Global Disseminator of Knowledge.

Gornostaeva, G., Rieple, A., \& Barnes, D. (2014). The role of networks in fashion designing: Disconnect between designers and manufacturers in London. Paper presented at the 19th DMI: Academic Design Management Conference 'Design Management in an Era of Disruption', 2-4 September, London.

Henry, C., \& de Bruin, A. (2011). Introduction. In C. Henry \& A. de Bruin (Eds.), Entrepreneurship and the creative economy: Process, practice and policy. Cheltenham: Edward Elgar.

Hill, J. (2001) A multidimensional study of the key determinants of effective SME marketing activity: Part 2. International Journal of Entrepreneurial Behaviour \& Research, Vol. 7 No. 6, 2001, pp. 211-235. 5 MCB University Press, 1355-2554.

Kotler, P. and Keller, K.L. (2018). Marketing Management, $15^{\text {th }}$ ed. Pearson Education Limited, Harlow, United Kingdom.

McCarty, E Jerome, \& Perreault Jr, Willaiam D, 1993, Dasar-dasar Pemasaran, edisi 5, Erlangga Jakarta.

Mills, C. E. (2011) Enterprise orientations: A framework for making sense of fashion sector start-up. International Journal of Entrepreneurial Behaviour and Research, 17(3), 245-271.

Nuseir, Mohammed T (2018). Digital Media Impact on SMEs Performance in the UAE, Academy of Entrepreneurship Journal, Vol 24.

Polat, G. and Donmez, U. (2010) ANP-based marketing activity selection model for construction companies. Construction Innovation, Vol. 10 (1) pp. 89 - 111. http://dx.doi.org/10.1108/14714171011017590.

Slamet, F., Tunjungsari, H.K., Ie, M. (2018). Dasar-Dasar Kewirausahaan, Edisi 3, Jakarta: Indeks. Yuanyuan, W., \& Shikui, W. (2016). Managing ambidexterity in creative industries: A survey. Journal of Business Research, 69, 2388-2396. 